\title{
A Suggestion on Mortgage Financing of Islamic Banks: Diminishing Musharakah
}

\author{
Yusuf Dinc
}

\begin{abstract}
Participation banks can produce house financing based on mortgage in Turkey. Mortgage of participation banks of Turkey is a type of Murabaha financing. Murabaha financing model is based on buying in advance and selling on credit terms. Other financing models of interest-free banking are not applied to mortgages of participation banks in Turkey. Diminishing Musharakah is an interest-free financing model for any type of credits and also applied to mortgages in the world. In this essay Diminishing Musharakah is argued as a unique financing model of interest-free banking. Also applicability of Diminishing Musharakah for Turkish participation banks' mortgages is evaluated. The findings that were obtained in Turkey may be generalized for the other regions of the world."
\end{abstract}

Index Terms-Diminishing musharakah, mortgage, Islamic banking, participation banking, Sukuk.

\section{INTRODUCTION}

The financing that is realized with house purchase is called as mortgage in Turkey. Mortgage proceedings are realized in Turkey based on the Law on Amendments in Various Laws on Mortgage Financing System and on additional regulations. The standard of this application is the same for conventional banks and participation banks. The difference in practice had developed in the way in which participation banks purchased the house in cash by proxy, and then sold it to the customers in installments. In this way, the proceedings were made to comply with Islamic Jurisprudence.

On the other hand, several other methods that comply more with the participation banking principles have been developed in the world. One of these methods is the Diminishing Musharakah, which means a special form of partnership. For example in Pakistan, Islamic Banking Institutions perform mortgage financing with the Diminishing Musharakah Method [1]. The reason why participation banks are preferred in Turkey for mortgage is the sensitivity of the clients on costs as well as on interests. The basic priority is the search for the best practice of the permission for the proceedings in Islamic Jurisprudence.

The Diminishing Musharakah is a type of Musharakah, which is a special form of partnership. The term "musharakah" does not exist in classical Islamic Jurisprudence books, it has been developed with modern

Manuscript received December 12, 2016; revised February 7, 2017.

Yusuf Dinç is with the Islamic Economics and Finance Department, Faculty of Business and Management Sciences, Istanbul Sabahattin Zaim University, Istanbul, Turkey (e-mail: yusuf.dinc@izu.edu.tr). terminology [2]. Musharaka means the establishment of a partnership by two or more people by investing certain amount of capital to share the profit or the loss that may occur when doing the planned job [3]. This abovementioned certain amount may be equal or different for the partners [4]. The partnership occurs with the capital and labor in the musharakah system. The parties of musharakah may participate in the partnership by investing capital in addition to labors in an active manner, some of the parties may only participate with their labors [5]. Participating with labor may be in the form of administration, while it may also be in functional level [4]. Musharakah is also called with the name "partnership in capital" [6]. It is called as Profit-Loss Sharing [4] in the world which means the partnership for profits or losses or as Joint Venture. Musharakah is a method of collecting funds as well as a method in which the clients are made to use the funds. The characteristics of making clients use funds have been determined after being discussed in terms of change, conversion, fragmentation, and termination [6].

The application of musharakah has an application in the form of normal musharakah, and it may also be applied in various other methods. One of these methods is Musharakah-i Mutenakısa [7]. Musharakah-i Mutenakısa is also called as Musharaka-i Tanazoleya. It is called as Digressive or Diminishing Musharakah in the world. It is also called as the partnership that ends with the transfer of ownership [7]. In this context, there is a partnership based on the sharing of the profit/loss that may occur as a result of the running of a project by the bank and the project owner, and the agreement ends with the transfer of the rights in the partnership after some time [7].

Based on the regulations, the obligation of the party demanding financing for mortgage having a participation at a certain amount, in other words, the participation bank being capable of paying a limited amount of the project means that current mortgage financing methods are close to basic musharakah method. In other words, both parties take part in the project with their current capital assets. The necessary grounds for diminishing musharakah was prepared with the current application, because it is necessary in musharakah that both parties have capital assets in the project to be realized.

\section{MORTGAGE}

Mortgage is the basic housing finance method that has found wide area of application in nearly all over the world. The method has been developed to enable people with lowincome levels to purchase a house by providing long-term credit opportunities. 


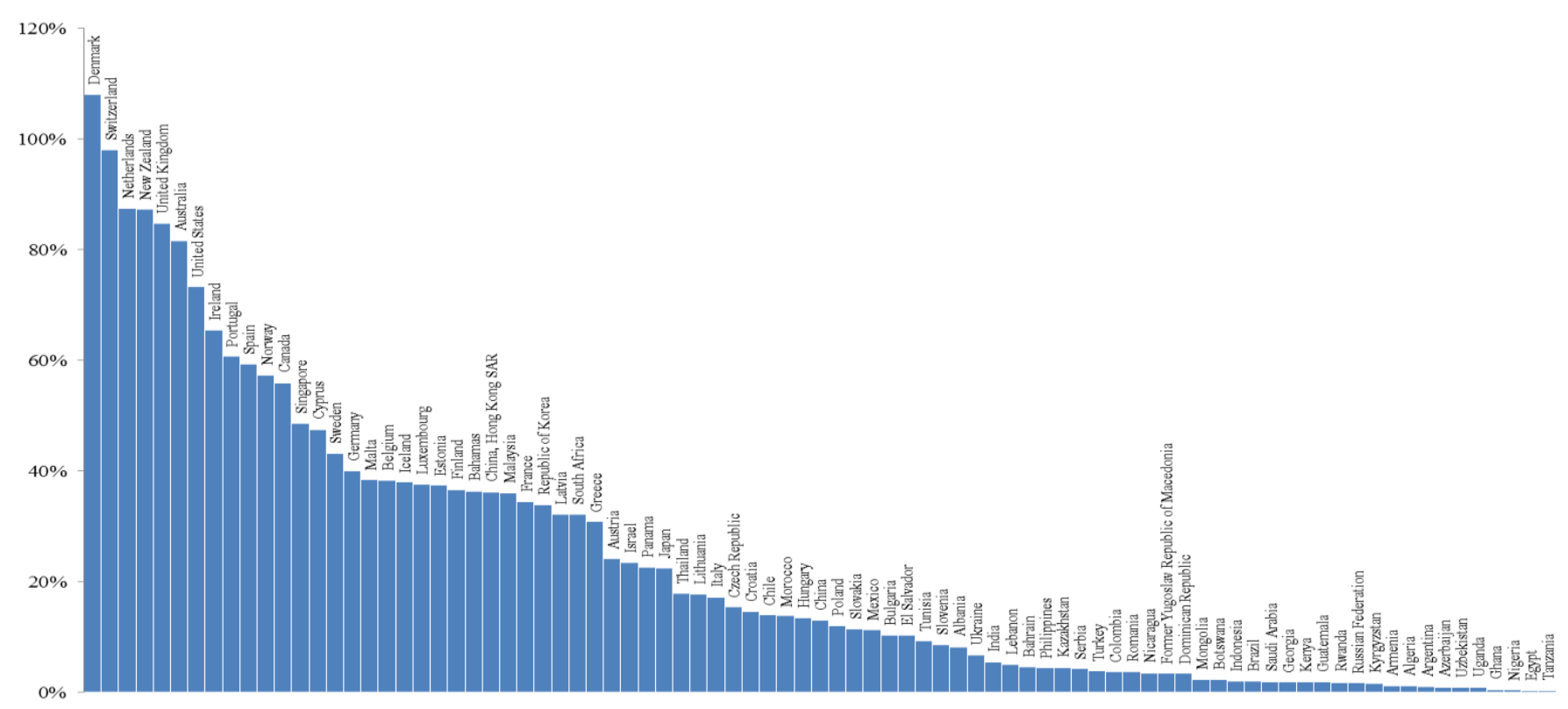

Fig. 1. The rate of mortgage financing to GNP 2006-2010. Source: Badev et al., 2014; 7 [8]

Fig. 1 shows the rate of mortgage financing to GNP which Turkey is around $10 \%$. In Turkey, mortgage proceedings were realized as based on the Law on Amendments in Various Laws on Mortgage Financing System and on additional regulations with the date 30.12.2012 and with the number 28513 after it was regulated in Capital Market Law 6362, Item 57, and the use of mortgage loans became widespread, and its share in total credits increased. Mortgage is a type of Consumer Credits.

TABLE I. The Developments In CONSUMER LoAns And MoRTGage LOANS (MILLION TRL) (ALL SECTORS)

\begin{tabular}{lcccccc}
\hline \multicolumn{1}{c}{ Year } & 2015 & 2014 & 2013 & 2012 & 2011 & 2010 \\
\hline $\begin{array}{l}\text { Consumer } \\
\text { Loans }\end{array}$ & 305,844 & 281,543 & 247,515 & 193,369 & 167,017 & 126,931 \\
$\begin{array}{l}\text { Mortgage } \\
\text { Loans }\end{array}$ & 143,247 & 125,371 & 109,680 & 85,127 & 73,269 & 58,830 \\
\hline
\end{tabular}

Source: BDDK (Banking Regulation and Supervision Agency - BRSA)

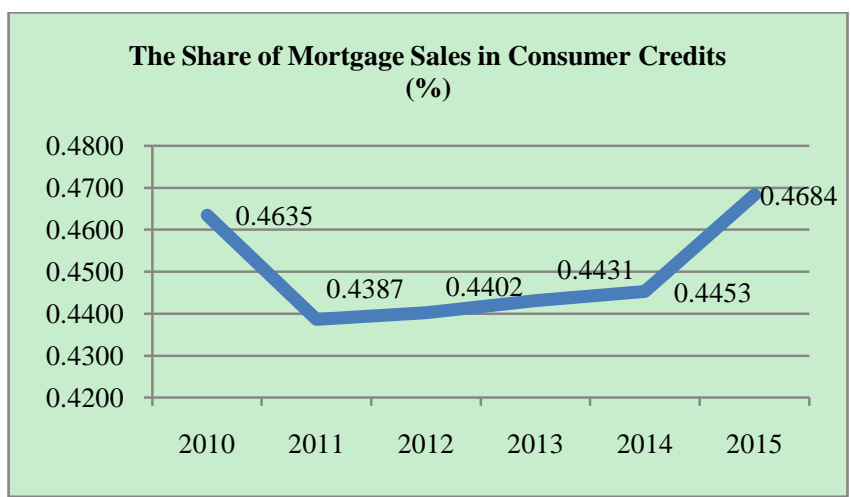

Fig. 2. The share of mortgage sales in consumer credits in Turkish banking system.

As it is observed in Table I, mortgage rates are increasing as amounts in the Turkish Banking System. There was an increase at a rate of $143 \%$ between the years 2010 and 2015 . The share of mortgage has also increased in Total Consumer Credits. It is observed in Fig. 2 that the share of mortgage in Total Consumer Credits was 43,9\% in 2011, and increased to $46.8 \%$ in 2015.

Mortgage rates have a bigger share in participation banks.
It is observed in Table II and Fig. 3 that the share of mortgage in participation banks in Consumer Credits was around $90 \%$.

TABLE II. The Developments In CONSUMER CREDITS AND MORTGAGE CREDITS OF PARTICIPATION BANKS

\begin{tabular}{lcccccc}
\multicolumn{7}{c}{ (MILLION TRL) } \\
\hline \multicolumn{1}{c}{ Year } & 2010 & 2011 & 2012 & 2013 & 2014 & 2015 \\
\hline Consumer & $3,615.05$ & $5,426.62$ & $7,143.82$ & $9,952.59$ & $12,015.15$ & $13,954.81$ \\
$\begin{array}{l}\text { Credits } \\
\text { Mortgage }\end{array}$ & $3,227.04$ & $4,913.94$ & $6,531.04$ & $9,061.39$ & $10,866.67$ & $11,997.78$ \\
Credits & & & & & &
\end{tabular}

Source: BDDK (Banking Regulation and Supervision Agency - BRSA)

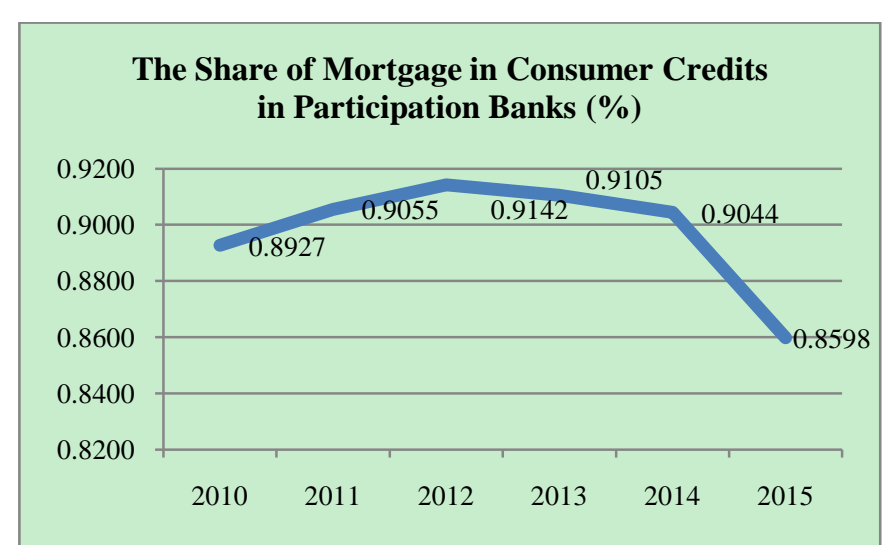

Fig. 3. The share of mortgage sales in total consumer credits in participation banks.

The share of mortgage in Consumer Credits in participation banks is relatively high. This situation ensures that a sound guarantee structure appears. As a matter of fact, mortgage is performed with the real property encumbrance system. The major part of the other Consumer Credits is open credits. The share of mortgage among Consumer Credits in participation banks being high is the result of the interest-free financing being capable of involving only one purchase-sale agreement. On the other hand, the share of mortgages being lower in the whole sector than the participation banks is due to the fact that conventional banks are capable of making direct payments to the clients that demand personal finance credits. The mortgage 
applications in Turkey may be financed up to the limits of $75 \%$ of the expertise value.

The Regulation on Credit Proceedings of Banks that was released in the Official Gazette on 1/11/2006 with the number 26333 organizes the credit proceedings of the conventional and participation banks. In Item $12 \mathrm{~A}, 1^{\text {st }} \mathrm{Sub}$ clause of this regulation, it is stated that an amendment was made in this regulation in the Official Gazette with the date 31.12.2013 and number 28868 as follows;

"The rate of the credit amount to the value of the house may not exceed seventy-five percent in in mortgage credits or in financial leasing transactions except for vehicle loans. It is compulsory that the value assessment of the real estate that is taken as guarantees be made by the appraisal companies defined by the Capital Market Board in these limited bank loans; and these values must be used in limitations."

A limitation of $75 \%$ was enacted and applied as of its release date. This limitation prepares the ground for investing a certain amount of capital that is necessary for the establishment of musharakah. The term "preparing the ground" is related with the prevention of loss of competitive advantage by the condition of having a capital being invested in musharakah because it is not possible to finance the whole of the mortgages and because the regulation has brought a standard for all the banking system.

\section{DIMINISHING MUSHARAKAH}

Diminishing Musharakah is technically defined as the cooperation between two parties on a project provided that the rights of one of these parties decrease [9]. Diminishing Musharakah is the basic instrument of mortgage financing when the interest-free practices in the world are considered [10]. According to Saeed, Diminishing Musharakah may be applied on everything whose value may increase such as houses, taxi license plates, etc. [11].

Financing models have been developed for interest-free housing financing. The interest-free house financing model has not been developed by the participation banks in Turkey except for murabaha that is based on house cash purchase and on sales by installments. On the other hand, bay bitamam ajil and Diminishing Musharakah are used more commonly than the other interest-free financing models. In interest-free financing practices in areas and countries like the Gulf area, the United States of America, Australia, Germany, Canada, England, and similar other countries, Diminishing Musharakah is the basic house financing method [12]. It is observed that the Diminishing Musharakah model is called as "direct house financing" because of its common use in house financing practices [13].

Diminishing Musharakah is a financing type that is based on decreasing partnership concept. In Diminishing Musharakah Method, one of the parties undertakes that s/he will purchase the shares of the other party [13].

In this situation, the bank is in the position that undertakes that it will sell its share, and the party that demands financing undertakes that $\mathrm{s} /$ he will purchase this share [14]. The share of the profit the bank will receive decreases when the share of the bank decreases [4]. In this situation, the share of the other party that will be received from the profit will increase together with the partnership share.

Diminishing Musharakah is realized in two ways. The first one is the Direct Musharakah Model, and the other one is the combination of musharakah and leasing agreements to provide financing. According to one the models of this financing method that has been reflected in the practice, there is the condition that makes it compulsory to re-pay the profit-loss share per stocks of the banks in installments. As the installments are paid, the partnership share of the bank decreases; and with the latest installment, the asset that is the subject matter of the partnership becomes no longer the shared property of the bank [6]. In this context, let us assume that there a mortgage financing project involving 100 thousand TL. According to the regulation, the party that demands the financing participates in the partnership with at least $25 \%$ project capital of the total amount. Let us assume that 25 thousand TL are paid. In this case, the bank will pay 75 thousand TL. The mutual ownership established in this way. This proceeding is called as Şirket-i Milik [12]. After this step, the party that demands the financing accepts the payment plan showing that s/he will pay the profit and the share of the bank in a periodical manner. In this way, the share of the bank decreases in every payment period, and at the end of the repayment period, the whole ownership of the property is held by the party that demanded financing. The rule of "paying the partnership share after the project is completed" in classic musharakah [15] is thus spread to periods and the Diminishing Musharakah is established.

A second way for this is the bank's transferring its share in the form of "leasing financing", which is also called as "leasing". If we continue over the same example, the bank rents its $75 \%$ share to the party that demands the financing. The payments and the durations of the rent are determined with an agreement. As the share of the bank decreases, the amount of the rent is also decreased. This situation also fits the decreasing capital-profit balance in current practices in Turkey. With the payment of the last rent, the ownership of the property is transferred to the party that demanded the financing [12]. Diminishing Musharakah with leasing is used more commonly for purchasing houses. In the practices in Pakistan, the rent or the profit share is assessed in Karachi Inter Bank Offer Rates, which is also known as KIBOR [16]. It is known that the profit rates of the classic musharakah model in Turkey are determined with a margin established on LIBOR. According to Saeed, both methods may be used for mortgage purposes. These methods are intended to obtain fixed or varying rent income. In this method, as the share of the interest-free financial intermediary institution decreases, the amount of the rents the amounts of the rents are re-considered in favor of the second party. In this method, the insurance and similar costs are accepted within the calculations [16].

Diminishing Musharakah is important as a financing form that is specific to participation banks and distinguishes them from conventional banks. Diminishing Musharakah brings an important alternative to the mortgage practices of conventional banks [13].

Diminishing Musharakah is important for stability in economy [12]. In addition, it may also have a role that prevents economic crises based on mortgage [13]. In a study 
conducted on this topic, Jensen [17] emphasized Diminishing Musharakah as a successful method in preventing mortgage credit shocks. It is absolutely certain that an auto-auditing mechanism in which house assessments are considered will come into being with Diminishing Musharakah.

Diminishing Musharakah has benefits when compared with Classic Musharakah. In classic Musharakah, the partnership share may be taken back all in once and at the end of the project; in Diminishing Musharakah, the capital is re-collected during the project period, and therefore, a certain amount of the capital is received back in case of a possible risk [18]. In other words, it provides a structure that decreases the risks of classic Musharakah. In Murabaha, on the other hand, it is the sole security preference of the interest-free financing institutions in volatility and uncertain situations [19]. The criticisms on Diminishing Musharakah are related with the complexity, agent problem, reliability and the termination of the project [20].

The replies to these critics may be found in the modern financing system. Today, all kinds of financial products have become more or less complex. The problem of agent and reliability has been overcome with the strict auditing of the public authority and financial institutions and with intense regulatory precautions. In classic Musharakah, the start of the termination may be defined as the moment when the costs about the project end, in other words, the moment when the profit and loss may be computed. Since the costs are terminated after the first purchase moment in mortgage financing, the profit or the loss may be computed. Musharakah does not have a fixed procedure, and various agreements may be established, and therefore, it has a strong side that responds to the criticisms; and moreover, it complies with possible changes that may occur in time and regulations [21].

Diminishing Musharakah is also the subject matter of Islamic micro financing [22]. In addition to this, it emerges as an efficient argument in measuring the size of the demand in mortgage and in determining the fields that may be invested in. The development of Islamic financing may contribute to the parallelism of micro financing via Diminishing Musharakah. Islamic finance and microfinance may be assessed as a whole that provides strong alternatives because of the challenges in realizing the investment plans of people with conventional ways. Islamic microfinance has the quality of nurturing the Islamic literacy and total financial literacy. Diminishing Musharakah is a product that has emerged in the forefront of Islamic microfinance. It may be used as a step in spreading the interest-free products to the common people.

Since Diminishing Musharakah is considered among the assets of interest-free financing institutions, is also comes to the forefront as an instrument of Islamic bonds that may be the subject matter of being transferrable [23]. In this way, the reproduction of interest-free finance instruments becomes possible. In addition, it may also provide capital support for interest-free financing institutions in computing the risk burden by forming a guarantee based on the houses to compute the capital adequacy ratio. The possibility of a successful risk management plan is thus presented to interest-free financing institutions with the help of being transferrable property in Diminishing Musharakah. In addition, the being transferrable property provides a second impact that empowers the capital in computing the capital adequacy; and the risk being spread and being kept out of the balance sheet contributes to the establishment of a sound financial system based on Diminishing Musharakah and on the export of Islamic bonds.

\section{A. Islamic Jurisprudence Evaluations on Diminishing Musharakah Application}

There is a permission given by Islamic authorities on Diminishing Musharakah Model [13]. According to some researchers like Bendjilali and Khan, Muhammad Taqi Usmani, mortgage financing by Diminishing Musharakah has a healthier permission structure than the bay bittamam ajil and murabaha financing [12].

Diminishing Musharakah is a derivation of belief according to the AAOIFI standards [24]. Similar to the determinations of Hanif, according to some other researchers, Diminishing Musharakah has a permission given by Islamic thinkers [25]. In First International Conference on Islamic Banking held in 1979 in Dubai, several viewpoints were set forth on the suitability of Diminishing Musharakah.

According to AAOIFI standards, Diminishing Musharakah has been defined as "the partnership in which one of the partners undertakes that it will purchase the shares of the other party/parties in installments/is periods to ensure that the project that is the subject matter of the partnership is transferred to the party that demands the financing" [24]. However, it is not made compulsory that the partnership shares will be decreased and purchased-sold in the partnership agreement. This situation is a requirement of the belief company, and the existence of such a condition in the partnership agreement disrupts the permission [24]. The profit share rates must be determined at the beginning of the agreement. In case the shares decrease, it has been allowed that the profit share rates may be changed during the partnership period [24]. The Islamic Standard of AAOIFI on Partnership and Modern Partnerships was released on Rebiülev-vel, 4, 1423/May 16, 2002.

The AAOIFI Islamic Jurisprudence Council accepted the Islamic Standard on Partnerships and Modern Partnerships in the $8^{\text {th }}$ Meeting in Medine-i Munewwara on Safer 28, Rebiulevvel 4, 1423 / May 11 - 16, 2002.

In Basic Musharakah, a profit payment at a fixed rate or amount may not be decided on [2]. This situation brings an uncertainty in the point of direct transaction with Diminishing Musharakah in mortgage financing. In addition, there are some criticisms like how the changes in prices of the houses will be reflected in the partnership shares.

The practice of leasing musharakah may be considered to be more applicable in this term. It is compulsory that the rent and agreement duration is determined in the beginning. According to Shah et al., the difference of this transaction from the conventional mortgage is the fact that the bank undertakes the risk [16]. The guarantee of fixed revenue under the name of musharakah is a topic of criticisms [26].

Hasan [27], Siddiqi [28], Hasan [29] criticized Islamic financing in general terms claiming that the transactions have the quality of being the imitation of conventional banking or adopt the conventional banking products in 
which interest-free financing models are used.

Despite the criticisms, it is understood that Diminishing Musharakah is an instrument that has received permission from Islamic scholars, and may be assessed and developed as mortgage financing.

In case there appears a need for changes in legal proceedings in countries where Diminishing Musharakah is applied, these changes may be applied. In the United Kingdom, the difficulties in Diminishing Musharakah were eliminated with the changes in Tax Law, in Finance Act [30].

The issue of with which the accounting registers in Diminishing Musharakah will be examined is controversial in Turkey. If it will be considered under the title of Credits Units, it will be the subject matter of Banking Insurance Transaction Tax (BSMV). In addition, it will be the subject matter of corporate taxes. In case it is considered in participations unit, it will be exempt from BSMV, and interest-free institutions will have advantages in corporate taxation. However, in this situation, the costs and practices in purchase-sales must also be regulated. In present situation, Musharakah transactions are considered under the title of credits as an accounting process, and the partnership conditions are not reflected in the balance sheet and taxation and are limited with the agreement.

\section{B. Diminishing Musharakah Applications in Turkey}

The examination of the results that may appear due to the application of Diminishing Musharakah in Turkey is important in that the topic is discussed. In this context, we may examine a mortgage financing that is realized with Diminishing Musharakah and with Murabaha Financing with the date of Istanbul in a comparative manner. This comparison may be handled as the comparison of the mortgage financing and the financing by Diminishing Musharakah of participation banks and the mortgage financing with by the conventional banks.

It has been calculated by one of the important real estate sites calculating real estate indices that the average house prices as $\mathrm{m}^{2}$ in Istanbul are around 4.200 TRL, and average $\mathrm{m}^{2}$ rent amounts are 22 TRL [31].

TABLE III: THE REPAYMENT PLAN OF Diminishing MUSHARAKAH FinANCING

\begin{tabular}{|c|c|c|c|c|c|c|c|}
\hline \multirow{2}{*}{ 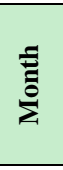 } & \multirow[b]{2}{*}{$\begin{array}{c}\text { Monthly } \\
\text { Rent }\end{array}$} & \multicolumn{2}{|c|}{ Share in the Rent } & \multirow{2}{*}{$\begin{array}{l}\text { Monthly } \\
\text { Share } \\
\text { Received } \\
\text { by the } \\
\text { Client } \\
\end{array}$} & \multirow[b]{2}{*}{$\begin{array}{l}\text { Client } \\
\text { Share } \\
\text { (TRL) }\end{array}$} & \multirow[b]{2}{*}{$\begin{array}{l}\text { Bank } \\
\text { Share } \\
\text { (TRL) }\end{array}$} & \multirow[b]{2}{*}{$\begin{array}{c}\text { Monthly } \\
\text { Payment } \\
\text { (TRL) }\end{array}$} \\
\hline & & $\begin{array}{l}\text { Client } \\
\text { (TRL) }\end{array}$ & $\begin{array}{c}\text { Bank } \\
\text { (TRL) }\end{array}$ & & & & \\
\hline 0 & $2200 \mathrm{TRL}$ & & & & 84000 & 336000 & \\
\hline 1 & 2200 TRL & 439.95 & 1759.80 & $5600 \mathrm{TRL}$ & 89600 & 330400 & 7359.80 \\
\hline 2 & 2200 TRL & 469.28 & 1730.47 & 5600 TRL & 95200 & 324800 & 7330.47 \\
\hline 3 & 2200 TRL & 498.61 & 1701.14 & $5600 \mathrm{TRL}$ & 100800 & 319200 & 7301.14 \\
\hline 4 & 2200 TRL & 527.94 & 1671.81 & 5600 TRL & 106400 & 313600 & 7271.81 \\
\hline 5 & $2200 \mathrm{TRL}$ & 557.27 & 1642.48 & $5600 \mathrm{TRL}$ & 112000 & 308000 & 7242.48 \\
\hline 6 & 2200 TRL & 586.60 & 1613.15 & $5600 \mathrm{TRL}$ & 117600 & 302400 & 7213.15 \\
\hline 7 & 2200 TRL & 615.93 & 1583.82 & $5600 \mathrm{TRL}$ & 123200 & 296800 & 7183.82 \\
\hline$\#$ & \# & \# & \# & \# & \# & \# & \# \\
\hline 58 & 2904 TRL & 2787.52 & 116.15 & $5600 \mathrm{TRL}$ & 408800 & 11200 & 5716.15 \\
\hline 59 & \multirow{2}{*}{$\begin{array}{l}2904 \mathrm{TRL} \\
2904 \mathrm{TRL}\end{array}$} & 2826.24 & 77.43 & $5600 \mathrm{TRL}$ & 414400 & 5600 & 5677.43 \\
\hline 60 & & 2864.95 & 38.72 & $5600 \mathrm{TRL}$ & 420000 & 0 & 5638.72 \\
\hline \multicolumn{2}{|c|}{ Total (TRL) } & 94.219.69 & 58.882 .91 & 336.000 & 420.000 & $\mathbf{0}$ & 394.882,91 \\
\hline & $\begin{array}{l}\text { liment } \\
\text { Jo }\end{array}$ & $\begin{array}{c}\text { Installment } \\
\text { Amount }\end{array}$ & $\begin{array}{l}\text { LE OF THE MO } \\
\text { Installment } \\
\text { Principal } \\
\text { Amount } \\
\end{array}$ & TGAGE FINAN & $\begin{array}{l}\text { ING WITH DA } \\
\text { tallment } \\
\text { e of Profit }\end{array}$ & $\begin{array}{c}\text { NISM SYST } \\
\text { Remain } \\
\text { Principa } \\
\text { Amount } \\
\end{array}$ & \\
\hline & & $0,00 \mathrm{TRL}$ & 0,0 & TRL & 0,00 TRL & 336.00 & 0,00 TRL \\
\hline & 1 & 7.271,99 TRL & $4.247,9$ & TRL & 024,00 TRL & 331.75 & 2,01 TRL \\
\hline & 2 & 7.271,99 TRL & $4.286,2$ & TRL & 985,77 TRL & 327.46 & 5,79 TRL \\
\hline & 3 & 7.271,99 TRL & $4.324,8$ & TRL & 947,19 TRL & 323.14 & 0,99 TRL \\
\hline & 4 & 7.271,99 TRL & $4.363,7$ & TRL & 908,27 TRL & 318.77 & 7,27 TRL \\
\hline & 5 & 7.271,99 TRL & $4.402,9$ & TRL & 869,00 TRL & 314.37 & 4,28 TRL \\
\hline & 6 & 7.271,99 TRL & $4.442,6$ & TRL & 829,37 TRL & 309.93 & 1,66 TRL \\
\hline & 7 & 7.271,99 TRL & $4.482,6$ & TRL & 789,38 TRL & 305.44 & 9,05 TRL \\
\hline & 8 & 7.271,99 TRL & $4.522,9$ & TRL & 749,04 TRL & 300.92 & $6,10 \mathrm{TRL}$ \\
\hline & $\#$ & $\#$ & & \# & \# & & \# \\
\hline & 59 & 7.271,99 TRL & $7.142,8$ & TRL & 129,15 TRL & 7.20 & $6,79 \mathrm{TRL}$ \\
\hline & 60 & 7.271,65 TRL & $7.206,7$ & TRL & $64,86 \mathrm{TRL}$ & & $0,00 \mathrm{TRL}$ \\
\hline To & & 436.319,06 TRL & $336.000,00$ & TRL & 319,06 TRL & & 0,00 TRL \\
\hline
\end{tabular}

In this context, let us consider a mortgage financing for a house of $100 \mathrm{~m}^{2}$. The total price of this house will be 420.000 TRL. The rent amount is determined as 2.200 TRL. Let the bank provide financing at a rate of $80 \%$, and let the client declared that $\mathrm{s} /$ he will perform a purchase of monthly shares at a rate of $1.33 \%$. In other words, the share of the bank will be terminated within 60 months by decreasing. Under these circumferences, the annual rent rate is 
computed as $6,25 \%$. Let us assume that there will be an increase over this rent amount at a rate of $8 \%$. This rate is around the consumer price index computed in Turkey for September 2016, which is taken as the reference value in the increase rate of the rents in Turkey [32].

The repayment plan of this financing will appear in the form given in Table I. In this context, as well as the bank payment When the fact that the difference between the costs stems from the difference between annual rent rate and annual Share of Profit rate is considered, the return of the mortgage financing project will occur with $6,25 \%$ costs as stated in Table III because there are no variables like in Diminishing Musharakah.

If the same project is realized in the form of conventional or murabaha financing with September 2016 costs, the repayment plan will be like the one given in Table IV.

The repayment of the project that was realized with monthly $0,90 \%$ Share of Profit ratio is calculated as 436.319 , 06 TRL. Although the cost of Diminishing Musharakah is around 58 thousand TRL, the cost of classic murabaha or conventional mortgage financing is around 100 thousand TRL according to September 2016 market conditions. In this context, Diminishing Musharakah is in favor of the client when compared with the conventional or murabaha mortgage financing.

When the fact that the difference between the costs stems from the difference between annual rent rate and annual Share of Profit rate is considered, the return of the mortgage financing project will occur with $6,25 \%$ costs as stated in Table $\mathrm{V}$ because there are no variables like in Diminishing Musharakah of 336.000 TRL; 58.882,91 TRL will be paid to the bank as rent payment together with annual increases. In this context, a total of $394.882,91$ TRL repayments will be made in 60 months.

In this computing, the increase in the value of the house has been excluded from the plan. The purpose here is to find the opportunity of comparing the conditions of murabaha.

In this situation, the cost of the project appears to be around 56 thousand TRL, and the client is in an advantageous situation according to the diminishing musharakah.

In today's market conditions, financing with diminishing musharakah that is in favor of the client brings a financial advantage. However, in periods when rents are equal to the murabaha Share of Profit rates, the bank has an advantage with the influence of the increases in the annual rent.

\begin{tabular}{|c|c|c|c|c|}
\hline $\begin{array}{l}\text { Installment } \\
\text { No }\end{array}$ & $\begin{array}{l}\text { Installment } \\
\text { Amount }\end{array}$ & $\begin{array}{l}\text { Installment } \\
\text { Principal } \\
\text { Amount } \\
\end{array}$ & $\begin{array}{l}\text { Installment } \\
\text { Share of Profit }\end{array}$ & $\begin{array}{l}\text { Remaining } \\
\text { Principal } \\
\text { Amount } \\
\end{array}$ \\
\hline 1 & 6,535.27 TRL & $4,784.71 \mathrm{TRL}$ & $1,750.56 \mathrm{TRL}$ & $331,215.29 \mathrm{TRL}$ \\
\hline 2 & 6,535.27 TRL & 4,809.63 TRL & 1,725.63 TRL & $326,405.66$ TRL \\
\hline 3 & 6,535.27 TRL & 4,834.69 TRL & $1,700.57$ TRL & $321,570.97 \mathrm{TRL}$ \\
\hline 4 & 6,535.27 TRL & $4,859.88 \mathrm{TRL}$ & 1,675.38 TRL & 316,711.09 TRL \\
\hline 5 & $6,535.27 \mathrm{TRL}$ & 4,885.20 TRL & 1,650.06 TRL & $311,825.89$ TRL \\
\hline 6 & 6,535.27 TRL & 4,910.65 TRL & 1,624.61 TRL & $306,915.23$ TRL \\
\hline 7 & 6,535.27 TRL & 4,936.24 TRL & 1,599.03 TRL & $301,979.00 \mathrm{TRL}$ \\
\hline 8 & 6,535.27 TRL & 4,961.95 TRL & 1,573.31 TRL & 297,017.04 TRL \\
\hline \# & \# & \# & \# & \# \\
\hline 59 & $6,535.27 \mathrm{TRL}$ & $6,467.70 \mathrm{TRL}$ & $67.57 \mathrm{TRL}$ & $6501.39 \mathrm{TRL}$ \\
\hline 60 & 6,535.27 TRL & 6,501.39 TRL & 33.87 TRL & 0 TRL \\
\hline Total & 392,116.2 TRL & 336,000.01 TRL & 56,115.93 TRL & \\
\hline
\end{tabular}

It may be considered that the duration that is found by dividing the annual rent amount, which is the return value of the house, to the price of the house may be influential in this situation. The financing of houses that have longer return durations with diminishing musharakah is advantageous. For example, the return duration of the project that is handled in Table III is 16 years. However, the financing of houses that have lower return durations with diminishing musharakah is disadvantageous for the client.

Since the main idea in interest-free financing is performing the proceedings in a method that best complies with Islamic Jurisprudence, the diminishing musharakah may be preferred in any case according to the Diminishing Musharakah Counseling Councils.

\section{RESULTS}

Mortgage financing come to the forefront with its benefits like profitability, periodical revenues, and strong guarantee structure, capital adequacy advantages for banking and interest-free financing institutions. The methods applied by interest-free institutions to provide healthy mortgage financing attracts attention in the whole world, and they provide strong alternatives.

The interest-free financing institutions in Turkey perform their mortgage financing activities with murabaha method. No different method shave been developed so far. The diversity in products in this topic must be run simultaneously with regulation infrastructure. Accounting, taxation, and purchase-sales topics must also be regulated. Diminishing Musharakah may supplement conventional banking in Turkey with its strong alternative financing method. The benefits that may be obtained in this method are multi-dimensional. Since Diminishing Musharakah is one of the Islamic micro financing instruments, it may be influential in spreading the financial literacy to common people.

Because Diminishing Musharakah is among the assets of interest-free financing institutions, it comes to the forefront as an important transfer source that may be the subject matter of Islamic bonds. The reproduction of interest-free instrument may be possible in this way. In addition, it may 
provide capital support for interest-free financing institutions in calculating the risk burden by forming a guarantee structure based on the house to calculate the capital adequacy ratio. The opportunity of a successful risk management may be realized with transfer method in Diminishing Musharakah to interest-free financing institutions. In addition, securitization also provides a second effect that will empower the capital in calculating the capital adequacy. In addition, the risk is spread to and kept outside the balance sheet, which ensures a contribution to the financial system together with Islamic bonds.

In today's housing market conditions, Diminishing Musharakah is in favor of the client when compared with the conventional methods or with murabaha method.

According to the findings obtained from the results, in mortgage loan costs, when considered with return duration of the house over the rent price, the debtor is in an advantageous position in case the return period is longer, and the creditor is advantageous position when the return period is shorter. These findings that were obtained in Turkey may be generalized for the other regions of the world.

\section{REFERENCES}

[1] M. Akram, M. Rafique, and H. M. Alam, "Prospects of Islamic banking: Reflections from Pakistan," Australian Journal of Business and Management Research, vol. 1, no. 2, pp.127, 2011.

[2] M. T. Usmani, "An introduction to Islamic finance," Maktab Maa'rul Quran, Karachi-Pakistan. pp.21, 2004.

[3] N. Hammâd, "İktisâdî F1kıh Terimleri" (trs: Recep Ulusoy), İstanbul, p. $318,1996$.

[4] M. A. A. Sarker, "Islamic business contracts, agency problem and the theory of the Islamic firm," International Journal of Islamic Financial Services, vol. 1, no. 2, p. 5, p. 4, p. 621,1999.

[5] R. Parlakkaya and S. A. Çürük, "Bir Yoksullukla Mücadele Aracı Olarak İslami Mikrofinans ve Türkiye'de Uygulanabilirliği," International Journal of Islamic Economics and Finance Studies, vol. 1, no. 2, 2016.

[6] S. Bayındır, "Bir finansman yöntemi olarak kullanilan sermaye ortakliğinin islâm hukuku açisindan değerlendirilmesi," Usûl, p. 140, p. 142,2005

[7] S. Bayındır, "Asya Ve Afrika Kültürünün Dünyaya Bir Armağanı: Faizsiz Bankacilik,” 38. Icanas, vol. 17, p. 24, p. 145, 2015.

[8] A. Badev, T. Beck, L. Vado, S. Walley, "Housing finance across countries: New data and analysis," Policy Research Working Paper, no. WPS 6756. Washington, DC: World Bank Group, p. 7, 2014.

[9] D. Siswantoro, H. Qoyyimah, "Analysis on the feasibility study of musharakah mutanaqisah implementation in Indonesian Islamic Banks," Islamic Economics and Finance, vol. 471, p. 472, 2007.

[10] Hussain, G. Rammal. (2016). Financing through musharaka: principles and application. [Online]. Available: http://www.islamicmortgages.co.uk/index.php?id=260

[11] A. Saeed, "Muslim Community Cooperative of Australia as an Islamic Financial Service Provider" in Abdullah Saeed and Shahram Akbarzadeh (eds.), Muslim Communities in Australia, Sydney: UNSW Press, pp. 188-205, 2001.

[12] M. Meera, A. Kameel, and D. Abdul Razak, "Islamic home financing through musharakah mutanaqisah and al-Bay' Bithaman Ajil contracts: A comparative analysis," Review of Islamic Economics, vol 9, no. 2, 5-30. p. 13 , p. 14 , p. $20,2005$.

[13] D. Hanif, "Differences and similarities in Islamic and conventional banking," International Journal of Business and Social Sciences, vol. 2, no. 2, p. 168 , p. 174 , p. 171 , p. $168,2014$.
[14] A. El-Galfy and K. A. Khiyar, "Islamic banking and economic growth: A review," Journal of Applied Business Research, vol. 28, no. 5, p. $943,2012$.

[15] H. Juwana, Y. S. Barlinti, and Y. K. Dewi, "Shaira law as a system of governance in Indonesia: The development of Islamic financial law," Wis. Int'l LJ, vol. 25, p.780, 2007.

[16] S. F. Shah, M. W. Raza, and M. R. Khurshid, "Islamic banking controversies and challenges," Interdisciplinary Journal of contemporary Research in Business, vol. 3, no. 10, pp. 1018-1026, pp. 1023-1024, 2012.

[17] N. C. Jensen, "Avoiding another subprime mortage bust through greater risk and profit sharing and social equity in home financing: An analysis of Islamic finance and its potential as a successful alternative to traditional mortgages in the United States,"Ariz. J. Int'l \& Comp. L., vol. 25, p. 825, 2008.

[18] B. Bendjilali and T. Khan, "Economics of Diminishing Musharakah," Islamic Research and Training Institute, Islamic Development Bank, p. 44, 1995.

[19] S. A. Rosly, "Critical issues on Islamic Banking and financial markets," Dinamas, Kuala Lumpur, p. 142, 2005.

[20] E. Smolo and M. K. Hassan, "The potentials of musharakah mutanaqisah for Islamic housing finance," International Journal of Islamic and Middle Eastern Finance and Management, vol. 4, no. 3, p. 239, 2011.

[21] M. T. Uusmani and U. M. Taqi, “An introduction to Islamic finance," Brill, pp. 29-30, 2002.

[22] A. R. A. Rahman and A. Rahim, "Islamic microfinance: A missing component in Islamic banking," Kyoto Bulletin of Islamic Area Studies, vol. 1, no. 2, pp. 38-53, 2007.

[23] R. Wilson, "Innovation in the structuring of Islamic sukuk securities," Humanomics, vol. 24, no. 3, p. 176, 2008.

[24] AAOIFI, "Finans Kuruluşları İçin Faizsiz Bankacilik Standartları," Çev. Mehmet Odabaşı (Giriş ve $1-13,15-19$ ve 33. Standartlar) Doç. Dr. İshak Emin Aktepe (14 ve 20 - 32 ve $34-41$. Standartlar), $T K B B$, İstanbul, 2012.

[25] A. K. Meera and D. Abdulrazzaq, "Home financing through the musharakah mutanaqisah contracts: some practical issues," Islamic Economics, vol. 22, no. 1, p. 14, 2009.

[26] I. Warde, Islamic Finance in the Global Economy, Edinburgh University Press, 2000. pp.5.

[27] Z. Hasan, Islamic Banking at the Crossroads: Theory Versus Practice, Islamic Perspectives on Wealth Creation, Edinburgh University Press, pp. 3-20, UK, 2005.

[28] M. N. Siddiqi, Banking Without Interest, The Islamic Foundation, Leicester, UK, 1983.

[29] Z. Hasan, "Credit creation and control: An unresolved issue in Islamic banking," International Journal of Islamic and Middle Eastern Finance and Management, vol. 1, no. 1, 69-81, 2008.

[30] M. M. Khan and M. I. Bhatti, "Islamic banking and finance: On its way to globalization," Managerial Finance, vol. 34, no. 10, pp. 708725, 2008.

[31] HURRIYETEMLAK. http://www.hurriyetemlak.com/Emlak-Endeksi/Detayli-Analiz

[32] TÜIKK. [Online]. http://www.tuik.gov.tr/UstMenu.do?metod=temelist

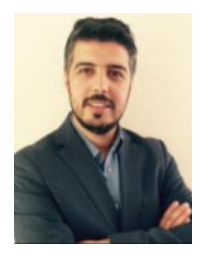

Yusuf Dinc was born in 1982. He started his education at Naval Academy then graduated from Department of Economics at Dumlupinar University. He made researches on corporate strategy of Aljazeera in Doha during MBA

Dinc started his $\mathrm{PhD}$ at Banking and Insuruance Institute of Marmara University. He worked at Law School of Duke University as research scholar in 2014 In 2015, he got his PhD in Banking Department of Institute of Banking and Insurance at Marmara University, Turkey.

Asst. Prof. Dinc, started his banking carrier at Albaraka Turk Participation Bank in 2007. He used to work at branches and investor relations department. Dinc, worked for Trakya University as Assist. Prof. from 2016 to 2017. He has essays on banking, shadow banking, and Islamic banking. He has been working as assistant professor at Istanbul Sabahattin Zaim University since 2017. Dinc is also a columnist for Yeni Birlik newspaper on finance and economics. 